\title{
Toni Morrison's Beloved as a Minor Art Practice: A Deleuze-Guattarian Reading
}

\author{
Naeem NEDAEE \\ MA in English Literature, University of Tehran \\ naeemnedaee@ut.ac.ir
}

\begin{abstract}
Toni Morrison's acute perception and treatment, in her novels, of the human and the postcolonial condition and her proposition of a problematics of individual and communal personhood have astounded contemporary readers and critics alike. This article aims to provide a DeleuzeGuattarian analysis of the workings of human relationships, human captivity and experiential writing in capturing the encounters between a sense of the self, a sense of the other and a remembrance of the past in Toni Morrison's Beloved. In this line, I argue that the text of Beloved instigates a formalistic deterritorialization of the English language by pushing it to the verge of non-signification. Through depicting a confrontation between traumatized ex-slaves and the haunting memories of captivity in the past, Beloved constitutes a minor art practice that gives rise to non-identitarian modes of selfconception and emancipatory lines of flight. I will also discuss how the clash between a dominating imperialist discourse with its claims to rationality and pragmatism on one hand and a specifically African-American worldview with a more open and inclusive perception of life's real possibilities on the other leads to the formation of multiple and heterogeneous assemblages of reality, memory and thought against pre-determined and ethnocentric values of being, identity and privilege. This marks Morrison's attempt in building up a cornerstone of minoritarian writing, a minor literature, in the Deleuze-Guattarian sense of the term.
\end{abstract}

Keywords: postcolonial condition, deterritorialization, minor literature, line of flight

\section{Introduction}

In their collaborative study Kafka: Towards a Minor Literature, Gilles Deleuze and Félix Guattari enumerate the three basic features of "minor" literature ${ }^{1}$. Firstly, as Deleuze and Guattari propose, a minor art practice denotes a form of expression that involves the "deterritorialization" of a major language and a "becoming stranger" within one's own tongue, however, with the crucial disambiguation that "[a] minor literature doesn't come from a minor language; it is rather that which a minority constructs within a major language" (Kafka 26, 16). This constitutes, as Simon O'Sullivan suggests in his "Notes Towards a Minor Art Practice," a counteractive yet productive framework whereby the extensive, representational, signifying qualities of a major language are undermined and, in a sense, foregrounded by the intensive, creative, non-signifying attributes of a minor language (par. 3). Deterritorialization works against the typical signifying processes inherent in a primarily extensive/ communicative language in the sense that it deprives language of its potential to make sense, causing it to stutter and stammer. What Deleuze and Guattari call an "intensive"/ "creative utilization" of a major language nullifies signification, taking language to the verge of "a new sobriety, a new expressivity, a new flexibility, a new intensity" (Kafka 22, 24). They point to African American's utilization of English, Godard's treatment of French and Kafka's own use of German as practical instances of minor practice. A probable consequence of such practice could be the

\footnotetext{
${ }^{1}$ See, especially Ch. 3 entitled, "What Is a Minor Literature?" (16-27).
} 
stultification of "order words" and the negation of power borne out by the "languages of masters" (Ibid. 26). As a corollary, a minor art practice does not occur from the outside, independently of a major cultural context. Rather, it functions from within and through the same materials but only using different procedures. In this respect, minor literature is not so much concerned with an antithetical binarism of the major and the minor but with a process of "becoming minor in the sense of producing movement from 'within' the major" (O'Sullivan, par. 7 original emphasis). Insofar as becoming minor involves the production of movements, a majority status is marked by stasis, fixation, immobilization.

Secondly, minor literature is informed with a particular sense of political immediacy and praxis (Deleuze and Guattari, Kafka 17). The political implications of a minor practice rest on the linking of the individual (personal, familial, marital) to the broader communal and social sphere. It is only by way of such a connection that non-signification, the deterritorializing force of the minor, can take on a direct political function and work to neutralize sense, to counteract the shades of representation. The formation of a relationship, and an opposition, between signification and nonsignification gives rise to a "political situation" that involves the interplay of the forces of domination and resistance, the workings of power (Ibid. 24). In fact, the minority status of an art practice lies in its potential to link up various regimes together and, in particular, to bring art into connection with the broader social sphere. This marks a turn away from both a certain kind of autonomous artistic engagement (art for art's sake, for instance) and typical forms of social and political practice. In the words of Simon O'Sullivan,

A minor art practice is not political in the sense that Politics is. It does not involve itself necessarily with political or what we might call molar organizations, rather it works to connect the different aspects of life, be they individual or social (or indeed nonhuman) so as to produce new lines of causality and new pathways of experimentation (precisely the production of what Guattari called 'molecular revolutions') (par. 14 original emphasis).

\section{Problematics of a minor literature in the post-colonial context}

As I noted in the introductory section, one of the direct political connotations of a minor art practice is that it does not take shape outside a major cultural discourse but that it functions from within and through the same elements. In "Gastarbeiterliteratur: The Other Speaks Back," Arlene Akiko Teraoka cautious us to construe this not as a "conciliatory or submissive" endorsement of the forces of representation and fixation but as a "potentially profoundly oppositional" gesture against a major literary and cultural tradition (100). This has certain implications that can provide us with entry points to the problematics of a minor literary practice, particularly in the post-colonial situation. Also as a corollary, we might wonder whether and how a minor writer in the post-colonial situation can effectively deploy elements of a major language or tradition and render it neutralized and devalued.

A first, relatively ironic implication, as one might deduce, is that the primary condition for a minor literature to emerge and to develop is the controlling presence of a major social force, which occurs in two stages: the dislocation of a prospective minority group from its original surroundings and collective identity followed by its reterritorialization through the definition of identity politics and subject positions. This is particularly of relevance to the post-colonial situation insofar as, for Deleuze and Guattari, the problem of minor literature is "the problem of immigrants, and especially of their children": It is a question of "becom[ing] a nomad and an immigrant and a gypsy in relation to one's own language" (Kafka 19). Still another implication with a relatively hopeful tenor, as pointed out by Delaney, is that the practitioners of minor literature "might be able to negotiate a discursive space from which to resist the cultural assumptions of the dominant group" (1). Well put in the words of Teraoka: "One position is that of cultural hegemony, the other, that of critique and resistance. One tries to reassert its dominance, while the other seeks to alter the dominant structures altogether" $(100)$. 
The deterritorialization/ displacement of a major language can be achieved by linguistic devices, termed by Deleuze and Guattari as "intensives or tensors," that "[bring] about an active neutralization of sense, [...] express the 'internal tensions of a language', [and] open the word onto unexpected internal intensities" (Kafka 21, 22 original emphasis). Such strategies, specifically developed by the language of a minor literature, range from a surface disruption of the dominant language structure (through the utilization of agrammatical forms - both lexical and syntactical - and the implementation of defamiliarizing techniques) to pushing language toward the zone of nonsignification and non-representation (through the insertion of elements of the minor - such as an oral tradition - into a majoritarian discourse and the aggrandizement of its supposedly representational, signifying practices). Deterritorialized language "stops being representative in order to now move toward its extremities or its limits" (Ibid. 23 original emphasis). It becomes no less a question of linguistic and discursive subversion than it is a matter of cultural invention and creativity in an affirmative approach to the positive forces of life and literary practice. As Réda Bensmaia suggests in her foreword to Deleuze and Guattari's book on Kafka, minor literature comes to rely not so much on a violent, destructive attitude than on a revolutionary spirit in its desire to come up with "a new way of using" the immediate materials of expression (XVI original emphasis).

A very powerful tactic in this respect, according to Delaney, is "the reversal of the established vector of 'content-to-expression' since [...] within a colonial context, for instance, imperialist epistemology and the discourse of type makes certain things near-impossible for the native writer to conceptualize or express" (2). Whereas the imitation of approved, dominant fictions secures the status of hegemonic powers by contributing to the persistence of the content-to-expression vector, a minor literature marks the potential for change by intervening in and reversing the established vector of the major discourse, where a general tendency for prioritizing content over expression permits certain control of reality. Such an intervention provides both the minor writer and the post-colonial individual with an alternative, "revolutionary" mode of expression which is primarily characterized by a tendency to "break forms, encourage ruptures and new sproutings" (Deleuze and Guattari, Kafka 28). This is what constitutes an "escape" from the determinations and presuppositions of a domineering imperialist discourse and its lure of mimetic representation. For Deleuze and Guattari, a minor literature is not a question of reaching freedom or "liberty as against submission" since one might be freed from slavery and yet be governed by the same system through the internalization of its oppressive exercises, as it is the case for Sethe in Beloved. On the contrary, it is a question of discovering paths of "escape" or "flight", "of a simple way out" and of a processional perpetuation of the process of deterritorialization (Ibid. 6 original emphasis, 13).

This brings us to a distinction between form of content and form of expression. According to Deleuze and Guattari, the interconnection of these two relatively independent forms provides us with entrances that open the way for experimentation with a text and from there they lead to more pathways, other connections. Such an entrance, as constituted by a reunion between form of content and form of expression, can take either a fluid form that proves conducive to the desire for experimentation or a rigid one that acts as a "functional blockage, a neutralization of experimental desire" (Ibid. 4). This might take the image of a "tobacco tin buried in [the] chest where a red heart used to be" (Morrison, Beloved 72-73) as a solid form of expression for suffocated passion and repressed memories: a visual blockage for a neutralized, oppressed or oppressing desire. Or, it might incorporate the sound of utterances that mingle into one another and counteract semantic valuations as a sonorous bloc for expressing an unconditional collective desire for freedom: "the sound that [breaks] the back of words" (Ibid. 261). Whereas the two forms of content stand opposed to one another in a dichotomous relationship, setting free-flowing desire against blocked passion, it is not so for the two forms of expression. Unlike the visual blockage, the sonorous block appears to be not a form of expression whatsoever but simply an "unformed material of expression" inasmuch as it 
activates deterritorialization (Deleuze and Guattari, Kafka 6). Through deterritorialization, even the most rigid formalizations of content give way to new lines of intensity at one point or another.

This is not an act of interpretation, of discovering "archetypes" that would regress into the imaginary of the writer or of finding "free associations" that would bring us back to repressed "memories" and "phantasms". Neither is it merely a search for "a structure with formal oppositions and a fully constructed Signifier; one can always come up with binary oppositions [and] bi-univocal relations" but this is senseless as long as one is unaware of the system's processes of becoming (Ibid. 7). Deleuze and Guattari's methodological act of taking entrances to a text rests primarily on experimentation, on finding points and passages that an entrance may possibly lead to even if it acts as an impasse. In this sense, a minor text, at both levels of expression and content, becomes an instance of the rhizome that resists "the introduction of the enemy, the Signifier, and those attempts to interpret a work that is actually only open to experimentation" (Ibid. 3).

This counteractive movement toward deterritorialization and the productive possibility of invention in art facilitate the emergence of a necessarily collaborative and collective site of expression. Two reasons can be of relevance here. First, a minor art practice concerns "people [who] live in a language that is not their own" (Ibid. 19) or, more precisely, in the words of Abdul R. JanMohamed and David Lloyd in their "Introduction" to Minority Discourse, it concerns "minority individuals" who share a certain cultural and political experience insofar as they "are always treated and forced to experience themselves generically" (10). As a corollary, collective expression becomes a tool in the hands of the minor writer to transform a "negative, generic subject position [...] into a positive, collective one" by providing insight into shared experiences of coercion and subordination and the workings of the established hegemonic order (Ibid.). Second, as noted by Deleuze and Guattari, "the political domain has contaminated every statement," particularly in a minority condition, so that a minor literature is invested with "the role and function of collective, and even revolutionary, enunciation [and the potential] to express another possible community and to forge the means for another consciousness and another sensibility" (Kafka 17). Once again, the problem of finding a line of escape/ flight for the minor writer and the post-colonial individual rests on the two complementary moments/movements of negation and affirmation.

The rupture, the line of flight emerges precisely where these two movements converge and, in a sense, become one since "the minority's attempt to negate the prior negation of itself is one of its most fundamental forms of affirmation" (JanMohamed and Lloyd 10). Accordingly, the critical task of the minor writer is to affirm a collective position by actualizing the negative and counterhegemonic force of the minor as an attempt to undo its negation - its coercion into an inferior, subordinate position by a dominant, homogenizing power. Therefore, according to Delaney, the counteractive nature of a minor art practice attains priority over the basic indices of the DeleuzeGuattarian paradigm - i.e. "deterritorialization, collective enunciation, and political praxis" - and finds a special resonance with the oppositional framework of the post-colonial condition (5). Even a successful deterritorialization of the major language, in the sense of decolonization, does not lead to a full resolution of the problem. Rather, as noted by Deleuze and Guattari, "the breakdown and fall of the empire increases the crisis [for as it] accentuates everywhere movements of deterritorialization, [it also] invites all sorts of complex reterritorializations - archaic, mythic, or symbolist" (Kafka 24). As William Christopher Brown points out cleverly, the "challenge" of all minority struggles, in this respect, lies in "ensuring that it does not reterritorialize language, [...] become an ossified, universalizing standard" 3 (3). In the following sections, I will provide a thorough analysis of how the

\footnotetext{
${ }^{2}$ Deleuze and Guattari also speculate that minor literature owes its collectiveness to an inevitable and equally advantageous "scarcity of talent" (Ibid). However, the lack of substantial historical evidence renders this statement as a mere conjecture.

${ }^{3}$ For Deleuze and Guattari, it is essential to "note the dangers of a minority struggle - to reterritorialize, to redo the photos, to remake power and law, to also remake a 'great literature"” (Kafka 86). In the same line, Paul Delaney legitimately argues
} 
text of Beloved, at both levels of expression and content, instigates a deterritorialization of the major colonizing discourse.

\section{Deterritorialization of a major language at the level of expression}

Now that I have surveyed the possibility of a minor literary practice in the post-colonial situation, it is time to consider in what terms and under what conditions the text becomes a site for minor expression. At the level of expression, Beloved is informed by "intensives" or "tensors" that counteract the conception of language as a designatory, representational, Saussurean structure. As a result, the narrative frees itself from traditional presumptions of meaning based in a fixed and fixating relationship between the signifier and the signified and turns into a fragmented, erratic and unbound rendition. The reason for this can be found in Morrison's statement that " $[t]$ o render enslavement as a personal experience, language must get out of the way" (Beloved XIII). The undoing of language with its claims to representation and meaning becomes a vital and crucial prerequisite for a faithful expression of the deplorable reality of slavery as suppressed and rendered unspeakable by that very language. In this line, a general feeling of oppression can be sensed throughout the text, which is occasioned by an indifference to standard grammatical forms. For instance, Beloved's response to Denver's questions about why and how she arrived at 124 Bluestone Road is marked by the use of the simple present tense for the reporting of past events and the use of incomplete phrases that stand as independent sentences. Technically, this disregard for syntactical rules can be taken as an effectual break with the colonialist discourse of domination and oppression.

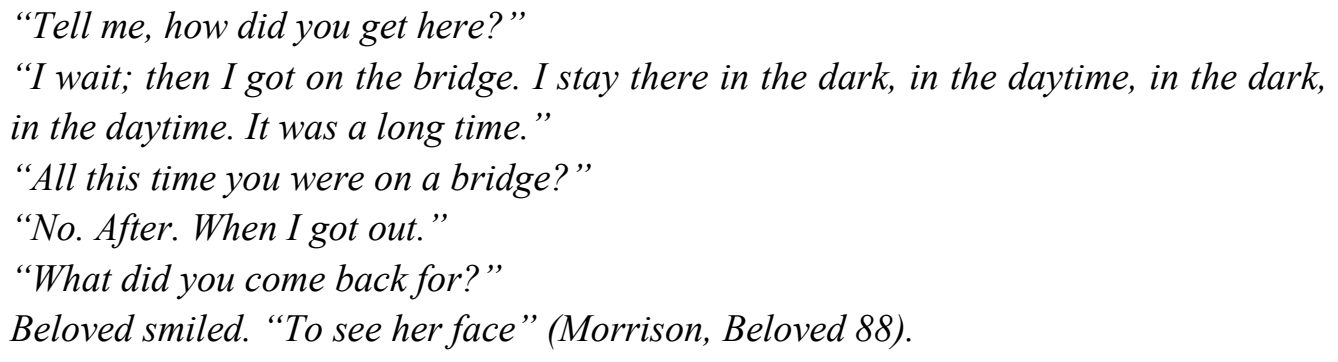

In the above quotation, sentences are interrupted, either begun or left in the middle, without coming down to the standard subject-predicate form. Although surface ruptures on the syntactical level prove essential to the deterritorialization of a major language, it is necessary to delve more deeply into the dynamics of Morrison's narrative and her manipulation of language that pushes it to the verge of dissolution, the point of its demise. One of the first examples of the stuttering and stammering of language occurs at the very beginning of the narrative where language fails to capture the absent reality of Beloved's ethereal presence. Beloved proves to be an elusive figure insofar as it is devoid of human attributes and cannot be clearly apprehended as a character, as a full verbal construct. As the opening lines of the novel suggest, Beloved can be at best conceived of as a personified consciousness whose body, whose language of the body is lacking:

"124 was spiteful. Full of a baby's venom. The women in the house knew it and so did the children. For years each put up with the spite in his own way" (3).

that "decolonizing nationalists" are predisposed to become major in their explicit "desire for reterritorialization [and in reaction to] the social and psychological dislocations suffered under colonial rule" (6). Also, in "Becoming Origin(al)," William Christopher Brown points to the way in which francophone postcolonial writers such as Bernabé et al. "inadvertently reterritorialize Creoleness despite their concerted effort at deterritorialization" (6). 
In this sense, Beloved's presence falls outside the reach and the limits of language, where writing becomes mute in the face of an unspeakable reality. This muteness, the lack of voice is a hint of historical oppression, cultural marginalization and dispossession of language. By recourse to imagination, Morrison compensates for this lack of voice and enables the language of slavery, as the language of a minor expression, to capture the unspeakable and to give voice to a silenced reality. As a result, language or writing, which conventionally functions as a relational binary structure in the Saussurean sense of the term, comes full circle without even finding the chance to refer to an intended external object or abstract concept. Language in its major status is displaced by a minor form of expression where the signifier-signified structure of the sign reverts to a monolithic whole, where such a relation does not exist in the first place. The lack of correlation, which is caused by the natural absence of a division in a minor form of expression, does hinder language from representation while allowing for a different form of signification by indirection, producing the real through narrative imagination.

Considered from a conventional perspective, communication involves "picking meaning out of a code" (62) through which an actualized spoken or written signifier, followed by an afterenunciation or silence, elicits an image or conjures up an association. However, when unspeakable experiences are rendered by a primarily communicative language, the signifier fails to evoke the image and the process of signification finishes off at the subsequent silence. Consequently, the signifier misses the signified and signifies nothing but itself. It is because of the decomposition of the linguistic sign that although Sethe could usually "see the picture right away of what she heard [...], she could not picture what Paul D said" (69). It is also for the same reason that Sethe fails to remember the past: "Nan [...] used different words. Words Sethe understood then but could neither recall nor repeat now" (62). Still at another point, the narrator describes the scene of murder with a sense of apathy, distance and indirection that parallels an elusive and ungraspable reality:

Inside, two boys bled in the sawdust and dirt at the feet of a nigger woman holding a blood-soaked child to her chest with one hand and an infant by the heels in the other. She did not look at them; she simply swung the baby toward the wall planks, missed and tried to connect a second time, when out of nowhere - in the ticking time the men spent staring at what there was to stare at - the old nigger boy, still mewing, ran through the door behind them and snatched the baby from the arc of its mother's swing (149).

The lack of details on and the perfunctory rendition of the act of murder illustrate the absence or impossibility of an adequate signifier that can evoke an unrepresentable and unspeakable, hence muted, signified. As long as the signified remains indescribable and inconceivable, language slides into the zone of non-signification and surrenders to absolute silence. A faulty attempt at representation can be found in the newspaper clipping that contains the story of Sethe's infanticide with her picture. In this case, the picture replaces the signified and becomes the target of the signifier or the document that claims to explain it, yet from a major perspective. Paul D betrays a skeptical attitude toward the clipping:

"The print meant nothing to him so he didn't even glance at it. He simply looked at the face, shaking his head no. No. At the mouth, you see. And no at whatever it was those black scratches said, and no to whatever it was Stamp Paid wanted him to know" (155).

Within the dynamics of a major language, substituting the unspeakable signified proves just as inefficient, leading no further than to an unfaithful representation. By extension, this is also true in 
the case of Beloved who, as a cryptic figure, escapes identification and whose name as a signifier fails to designate its presence. It is apparently in this sense that Beloved reflects, "there is no one to want me to say me my name" (212 original gap). Consequently, in a linguistic system of communication whereby signifiers miss or misrepresent signifieds, certain concepts or experiences will be prone to fall into oblivion:

Everybody knew what she was called, but nobody anywhere knew her name. Disremembered and unaccounted for, she cannot be lost because no one is looking for her, and even if they were, how can they call her if they don't know her name? (274).

Morrison's narrative is also endowed with a capacity to drive language toward the realm of non-signifying collective enunciation. To begin with, Beloved's reunion with Sethe and Denver is marked by a change of genre in the middle of the novel to a lyrical passage:

"Beloved/You are my sister/You are my daughter/You are my face; you are me/I have found you again; you have come back to me/You are my Beloved/You are mine [...]/You are my face; I am you. Why did you leave me who am you?/I will never leave you again/Don't ever leave me again/You will never leave me again/You went in the water/ I drank your blood/I brought your milk/ You forgot to smile/ I loved you/ You hurt me/ You came back to me/ You left me" (216-217).

A closer look at this poetical rendition reveals that it is composed of a multiplicity of voices instead of a single and singular subject of enunciation. Although the voices mingle into one another and cause the actualized components of the linguistic sign to constantly fluctuate between the signifier and the signified, it is still too soon for language to stutter, to cease to signify. In contrast, the blending of voices in the scene after Paul D leaves 124 effects a successful distortion of language:

What [Stamp Paid] heard, as he moved toward the porch, he didn't understand. Out on Bluestone Road he thought he heard a conflagration of hasty voices - loud, urgent, all speaking at once so he could not make out what they were talking about or to whom. The speech wasn't nonsensical, exactly, nor was it tongues. But something was wrong with the order of the words and he couldn't describe or cipher it to save his life (172).

The multiplicity of voices, the profusion of sounds deprives language of its object and leaves it in a state of absolute disarticulation. What remains of language is merely a whisper. In this regard, Morrison seems to have produced an unformed material of expression by her intensive utilization of a major language in the face of the totalizing and universalizing impulse of the colonialist discourse. However, as Deleuze and Guattari require, what should not be left out here is that "when a form is broken, one must reconstruct the content that will necessarily be part of a rupture in the order of things" (Kafka 28).

\section{Reconstructing the content: between and beyond the magical and the real}

At the level of content, Toni Morrison's Beloved is characterized by what one may refer to as supernatural occurrences and extraordinary presences that cannot be explained, at least conveniently, by the laws of the real and the experience of modern life. After being murdered by her mother to not experience a life of slavery, the eponymous character of the novel makes her presence known as a ghost through interventions in the physical world and, then, resurrects to life, embodied, in the flesh. Interestingly, Sethe and Denver digest both the incorporeal and corporeal manifestations of Beloved's presence as an ordinary incident, as unquestionable: 
Sethe and the girl Denver [...] waged a perfunctory battle against the outrageous behavior of that place; against turned-over slop jars, smacks on the behind, and gusts of sour air. For they understood the source of the outrage as well as they knew the source of light (4).

Baby Suggs in her own turn expects that her dead children are "worrying somebody's house into evil" (5). In the same manner, other women in the community discuss the reincarnation and the possible exorcism of Sethe's dead daughter as a natural occurrence and through matter-of-fact conversations:

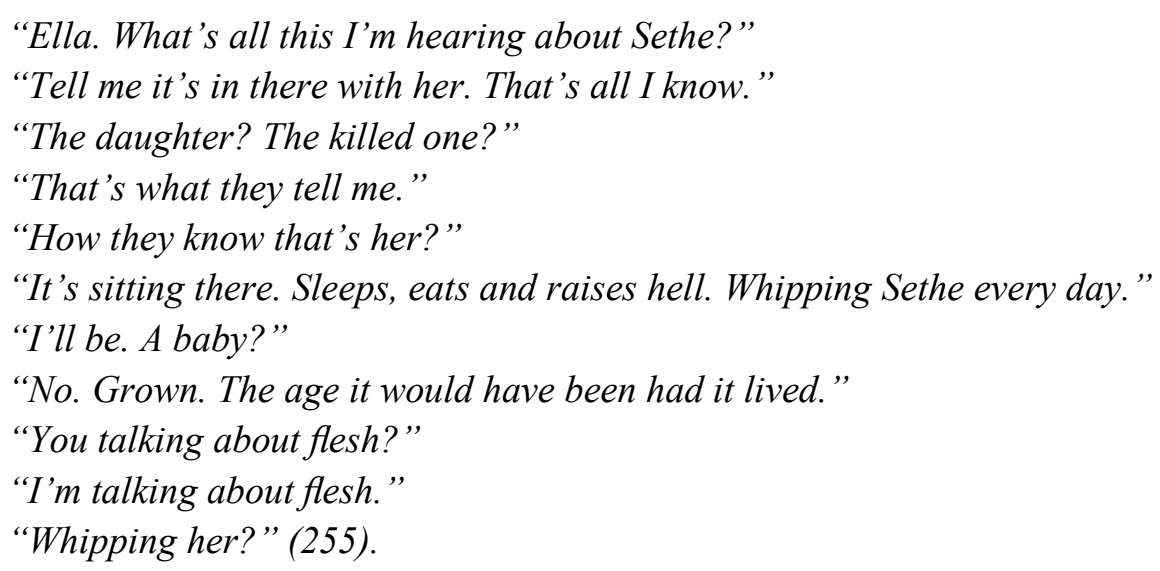

Not surprisingly, such clues have led many critics and readers to receive the novel as an instance of magic realism ${ }^{4}$. As a matter of common knowledge, magic realist texts are famous for their conflation of the real and the magical, which apparently seems applicable to Morrison's Beloved. However, in a conversation with Christina Davis, Morrison objects to this generic classification of Beloved and implies that the label is inefficient, even pernicious (225-226). Before rushing to make raw generalizations or stark reactions, it seems necessary to consider more fully what the notion of magic entails for certain conceptions of magic realism. Is a magical presence unreal? Or, is there a possibility of reconciling the magical with the real? And, what are the possible connotations of this label for the necessarily political and cultural conditions of the post-colonial situation?

In one of the earliest critical attempts at defining magic realism, literary critic Roberto González Echevarría traces the origins of the genre to three moments in history: an article on PostExpressionist painting by German art critic Franz Roh in 1925, the development of the literary concept lo real meravilloso by Cuban novelist Alejo Carpentier in a 1949 and a lecture by Mexican writer Angel Flores on a specifically Latin American magic realism in 1955, which marks the Latin American literary "Boom" of the late 1960s and 1970s (qtd. in Aldea 2). Obviously, none of these historical definitions seem to have provided us with so much of an adequate approach to the postBoom instances of magic realist novels. In compensation for this inadequacy, Echevarría introduces two forms of magic realism: a "phenomenological magic realism," which rests on a magical consciousness of the real where reality remains intact; and, an "ontological magic realism," which relies on the belief that the real and the magic, the natural and the supernatural coexist and on the claim that it belongs to a specifically Latin American experience and geography (Ibid.).

Another typology that follows the same line but expands Echevarría's notion of magic realism is proposed by William Spindler in his "Magic Realism: A Typology." Spindler distinguishes first of

\footnotetext{
${ }^{4}$ See, Rachel Lister's “Toni Morrison and the Novel," in Reading Toni Morrison (21) and Anne C. Hegerfeldt's Lies that Tell the Truth: Magic Realism Seen Through Contemporary Fiction from Britain (42-43).
} 
all a "metaphysical magic realism" which involves a defamiliarizing presentation of reality that does not go beyond "the limits of the natural" and inspires the reader or viewer "with a sense of unreality", which can be equated with Echevarría's definition of phenomenological magic realism where there is no magic as such (qtd. in Sandín and Perez 125-126). Prototypical examples of this mode of magic realism include Kafka's The Trial and The Castle where reality is presented in a sordid, unusual manner yet without the intervention of the supernatural (Herman 123). Second, as Spindler suggests, "anthropological magic realism" incorporates two distinct narrative "voices," "two contrasting views of the world" - one rational and empirical, the other magical and intuitive - "as if they were not contradictory." The resulting antinomy then is resolved by recourse to a certain cultural or mythical worldview or Weltanschauung which constitutes the "collective unconscious" of a social or ethnic group (qtd. in Sandín and Perez 126). The oppositional and cultural nature of this mode of magic realism resonates with a postcolonial struggle to reverse the hierarchy maintained by colonizing powers and removes the geographical specificity of magic realism to Latin America. "Ontological magic realism," the third term in Spindler's taxonomy, refers to texts whose resolution of the antinomy between rationality and magic does not depend on the involvement of a particular cultural perspective. Rather, the resolution is achieved through a matter-of-fact presentation of the supernatural "as if it did not contradict reason, and no explanations are offered for the unreal events in the text" (Ibid.). In this respect, Spindler seems to have revised Echevarría's ontological magic realism into anthropological and ontological magic realism based on the medium of resolution involved - socio-geographic factors or narrative manipulation. The principal instance of ontological magic realism includes Kafka's novella The Metamorphosis (Herman 123).

Wendy B. Faris proposes still another view that similarly advocates a resolution of the antinomy inherent to magic realism. Faris claims that magic realism must be conceived of as in opposition to realism, for its engagement with the extraordinary or the fantastic. Yet, the coexistence of the real and the magical is facilitated by realist descriptions and narrative features "in such a way that magical elements grow organically out of the reality portrayed" (163). In a turn of perspective, Amaryll Chanady grounds her definition of magic realism in opposition to the fantastic. Whereas in the fantastic no explanation is offered to resolve the implicit contradiction between "two distinct levels of reality," between the natural and supernatural, in magic realism "the supernatural is not presented as problematic" and the resolution is achieved by way of narrative devices such as authorial reticence and focalizers ${ }^{5}$ (qtd. in Aldea 11). Besides, several critics classify magic realism as a subset of postmodernism insofar as it, in certain cases, depends on narrative characteristics such as metatextuality, intertextuality, self-reflexivity and linguistic playfulness for its resolution of the antinomy ${ }^{6}$. A differing view, however, belongs to critics who consider the inherent antinomy of magic realism as irresolvable. For example, Anne Hegerfeldt posits that although supernatural interventions are "presented as though they are perfectly normal," a certain "tension" persists between the contradictory dimensions of the genre (qtd. in Lister 20). In the same vein, to Fredric Jameson, the magic realist text does not instigate a resolution of "the contradictions implied by the dual cultural context" of the narrative; but rather, it becomes the site for "a distinct clash of cultures," which

\footnotetext{
${ }^{5}$ As Aldea notes in her "Introduction" to Magic Realism and Deleuze, authorial reticence refers to the presentation of "the magical event" without an explanation to create the effect as if there were no contradiction between the natural and the supernatural, as if there were no need for explanation whatsoever. The focalizer is the agent of authorial reticence, the point of view from which the ordinary and the supernatural are juxtaposed and equated (11).

6 Among these textual features are: Jean-Pierre Durix's and Brenda Cooper's "self-reflexivity and metatextuality, playfulness and irreverence towards established cultural forms or categories," Frederick Louis Aldama's "the "mimesis-asplay' of intertextuality, metatextuality and self-reflexivity," Theo L. D'Haen's "intertextuality, metatextuality, deformation of time and space, bifurcation of plot," and Wendy B. Faris's "metafictionality, linguistic playfulness and self-awareness, repetition and intertextual reference" (Aldea 7-9).
} 
established magic realism as a basically political and historical narrative mode ("Magic Realism" $311)$.

At a closer analysis, however, both approaches reveal an internal inconsistency at explaining the apparent contradiction between the two codes of reality. On the one hand, if the resolution of the antinomy is maintained by realistic descriptions and a matter of fact treatment of the supernatural, e.g. through authorial reticence and focalizers, magic realism may arguably return to the realm of realism and the major discourse. Or, if postmodernist narrative characteristics are what facilitate this resolution, the political ideals of magic realism in the post-colonial situation may arguably be undermined by postmodernism's apolitical impulses and its disengagement with the real ${ }^{7}$. On the other hand, paradoxical solutions to the problem of contradiction, such as defining magic realism as "the simultaneous difference and non-disjunction between the real and the magic" (Aldea 18), not only fail to provide a convincing approach but also add to the complexity of the situation. With a closer look, one realizes that a simple matter-of-fact treatment of the supernatural does not make a text realist. For one thing, realism is concerned not merely with a surface form of expression that conforms to the principles of a communicative language but also with supposedly ordinary incidents that make up the content of the narrative whereas in magic realism the form of content also involves the supernatural, the extraordinary. For another, what remains of a magic realist novel with its marvelous elements taken out is not indeed a purely realistic narrative. Texts commonly read as magic realist, whether involving a clash of cultures or not, are often marked at the level of expression by techniques that diverge from a realistic tradition, such as intertextuality, metatextuality, selfreflexivity and so on. In this way, elements of the major language are effectually deterritorialized. The assimilation of such elements does not make the text major - they are incorporated only to be devalued and dislocated. Likewise, the mere occurrence of enigmatic incidents does not make a text anti-realist as long as rationally inexplicable events may always occur in real life. Setting a magic realist text or any text of hybrid nature within a framework of realism and the fantastic, a polarity constituted by post-enlightenment rationalism, would be a manifest mistake. Whether one considers a text that involves supernatural incidents as magic realist in a generic attempt, there is a prior need for doing away with the logic of termed polarity insofar as it is the product of an extensive and exclusionary worldview. Basically, we must avoid the common error of identifying realism with the colonizing force and the supernatural with a decolonizing agent since the opposition between the real and the magical is fundamentally a matter of Western, positivist perspective ${ }^{8}$. The emergence of a rupture, a line of escape in this polarized framework and the invention of an alternative reality do not necessitate a resolution of apparently contradictory components, a fusion that provides consistency and unification. Resolution is a concept that makes sense only if there is a belief in contradiction, in opposition. On the contrary, the encounter between the real and the magic, the opposition of which belongs to "them," the "whites," produces a rupture that opens out onto a third space which is multiple, at the same time real and magical and neither of them for that matter, devoid of the fundamental opposition that requires resolution or that involves irresolution. If we need to identify anything with resistance, or the decolonizing, non-Western, pre-capitalist point of view, it is an alternative, syncretic, trans-empirical reality and not anything else. A reality which is affirmative, intensive, inclusive and not negative, extensive or exclusive in its basis; a reality open to both the empirically real and the magically real. If anything is subversive of an exclusively empirical,

\footnotetext{
${ }^{7}$ As Jameson suggests, the cultural and political bearings of magic realism are evidently opposed to postmodern literature which is characterized by "depthlessness" and "a consequent weakening of historicity" (Postmodernism 6). For a similar argument, see Aijaz Ahmad's In Theory: Classes, Nations, Literatures (65).

8 Instances of such problematic alignment can be found in Fredric Jameson's statement that magic realism depends for its supernatural "raw material [on] peasant society, drawing in sophisticated ways on the world of village or even tribal myth" ("Magic Realism" 302) or similarly in Brenda Cooper's consideration of "the pre-capitalist worldview [as] a critical inspirational source" for the extraordinary nature of magic realist narratives (16).
} 
positivist worldview, particularly in the case of a cultural clash, it does not consist in prioritizing the magical over the real. The two are codes of one, trans-empirical reality. Magic is not unreal, it is not opposed to the real but only severed from the empirically real by the dominant capitalist mode of thought.

Morrison's deep concern with any polarizing/ polarized worldview in general and any reductionist approach to the African-American experience in particular now seems perfectly understandable. She points to the inefficiency and superficiality that underlie the generic classification of her work as magic realist:

I was once under the impression that that label [...] was a way of not talking about the politics, [...] about what was in the books. [...] It seemed legitimate because there were these supernatural and unrealistic things, surreal things, going on in the text. But for [...] literary critics it just seemed to be a convenient way to skip again what was the truth in the art of certain writers. My own use of enchantment simply comes because that's the way the world was for me and for the black people that I knew. In addition to [the real-life, practical knowledge], there was this other knowledge or perception always discredited but nevertheless there, which informed their sensibilities and clarified their activities (qtd. in Christina Davis 225-226).

Following Begoña Simal González, it is precisely in this sense that "the African-American collective conception of reality [...] contributes to the coexistence of two types of human knowledge: the analytic or scientific one and the 'sapiential' or synthetic one" (313). As Morrison tells Marsha Darling,

[T] he gap between the living and the dead and the gap between the past and the present does not exist. It's bridged for us by our assuming responsibility for people no one's ever assumed responsibility for (247).

Such rendition of the African-American experience reflects a holistic reality that transcends polarizing views of existence and knowledge. González clarifies that the novelist's practice is not that of "[setting] the realistic thesis (the possible) against the fantastic antithesis (the supernatural)," but that of going further, going beyond the opposition, toward a synthetic, syncretic and "trans-empirical" reality (314).

Beloved is characterized by a rather complicated, carefully thought-out structure. In the opening lines of the novel, the narrator provides the reader with information on a series of events the causes of which are to be unraveled only later in the narrative in pieces and fragments. The narrator archives this effect through the evocation of images and associations and the linking of the present to the past that activate memory and perception at the same time. As readers, we are informed of the following facts: "The grandmother, Baby Suggs, was dead, and the sons, Howard and Buglar, had run away" (3), Sethe had murdered her baby girl by "having its throat cut" (5), and She and Denver were moved to 124, which "was spiteful, [f]ull of a baby's venom" (3) and haunted by the ghost of the revengeful daughter. The moving back and forth of the narrator through time and space, memory and observation shapes the structure of the novel in a cyclical/ circular from. In one fragment of the narrative, this sense of shift and motion is projected onto the figure of Sethe as she tries desperately to tell Paul D, another ex-slave of the Sweet Home plantation, of the ordeals that she underwent both during her life as a slave and after she ran away from her masters. The fragment can be taken as a metatextual reflection on the text itself: 
She was spinning. Round and round the room. Past the jelly cup-board, past the window, past the front door, another window, the sideboard, the keeping-room door, the dry sink, the stove - back to the jelly cupboard. Paul D sat at the table watching her drift into view then disappear behind his back, turning like a slow but steady wheel (159).

Additionally, the narrative fragments progress with a growing intensity, incrementally providing clarification for the "spiteful" condition of the house and for the questions that are probably raised for the reader in the early section of the novel. The fragmented, cyclical nature of Beloved corresponds with its capacity to challenge the assumptions of a dominant colonialist attitude and to provide an alternative perspective to Eurocentric accounts of reality and history. Through repetition, association, imagery and memory, the text manages to juxtapose the present and the past to achieve an all-inclusive, omnipresent temporality that undercuts a sense of time based in the polarization of the present and the past. The residents of 124 are manumitted slaves whose present reality is profoundly contaminated by their traumatic, agonizing and dehumanizing experience of plantation life. No matter how hard the characters try to erase the tormenting presence of their memories, forgetting seems more and more impossible. Baby Suggs's experience highlights the penetration of the past into the present and the impossibility of escape from everlasting torment even through death:

Suspended between the nastiness of life and the meanness of the dead, she couldn't get interested in leaving life or living it, let alone the fright of two creeping-off boys. Her past had been like her present - intolerable - and since she knew death was anything but forgetfulness, she used the little energy left her for pondering color (34).

The only possible way then to relieve the anguish seems to be a direct encounter with the haunting presence of the past, or what Sethe terms "rememory":

I was talking about time. It's so hard for me to believe in it. Some things go. Pass on. Some things just stay. I used to think it was my rememory. You know. Some things you forget. Other things you never do. But it's not. Places, places are still there. If a house burns down, it's gone, but the place - the picture of it - stays, and not just in my rememory, but out there, in the world. What I remember is a picture floating around out there outside my head. I mean, even if I don't think it, even if I die, the picture of what I did, or knew, or saw is still out there. Right in the place where it happened (35-36).

In this sense, "rememory" takes on a collective and concrete manifestation that can be shared vicariously and independently of the rememberer with others, even with those who did not experience it first-hand. As a site for the convergence of the present and the past, rememory also produces, or is produced by, a form of temporality that is static, does not flow or pass, only lingers on and neutralizes the past-present dichotomy - hence, Sethe's statement that "[t]oday is always here, $[\ldots][t]$ omorrow, never" (60). In the case of Paul D and his experience of ceaseless humiliation and torture as one member of a group of chained slaves, the incessant rain produces the effect as if time had stopped or had dragged to eternity:

It rained./ Snakes came down from short-leaf pine and hemlock./ It rained./ Cypress, yellow poplar, ash and palmetto drooped under five days of rain without wind. By the eighth day the doves were nowhere in sight, by the ninth even the salamanders were 
gone. Dogs laid their ears down and stared over their paws. The men could not work. Chain-up was slow, breakfast abandoned, the two-step became a slow drag over soupy grass and unreliable earth (109).

Similarly, Sixo's constant experimentation with timing always seems to fail: "Time never worked the way Sixo thought, so of course he never got it right" (21). This is particularly evident in Sixo's scrupulous efforts for cooking, whereby he always ends up with "undercooked, overcooked, dried-out or raw potatoes" or in a night's plan for "a thirty-mile trip to see a woman [that leaves him with] just enough time to say good morning before he had to start back again" (Ibid.). In addition to traumatic memories that repeatedly bounce back and shatter a sense of linear time, the embodied presence of the baby ghost crosses the border between the dead and the living and makes the absent present. Apparently, Beloved seems to incarnate Sethe's murdered daughter as a grown-up woman, "[t]he age it would have been had it lived" (255). She also appears to be joined with the spirit of the dead in her "rememoried" experience as a woman who died of the ordeals of transition on a slave ship in the Middle Passage. In the following monologue, Beloved reflects on the horror, persistence and atemporality of that experience, which is marked by gaps and a lack of punctuation in the narrative:

All of it is now it is always now there will never be a time when I am not crouching and watching others who are crouching too I am always crouching the man on my face is dead [...] in the beginning the women are away from the men and the men are away from the women storms rock us and mix the men into the women and the women into the men that is when I begin to be on the back of the man for a long time I see only his neck and his wide shoulders above me [...] until he locks his eyes and dies on my face we are that way there is no breath coming from his mouth and the place where breath should be is sweet-smelling the others do not know he is dead (211-212 original gaps).

Morrison effectively links Beloved to a recovered history, to the "Sixty Million/ and more" to whom she dedicates the book in her epigraph to the novel. In doing so, she produces a rememoried and re-imagined history based on post-colonial heterogeneity as an alternative to the Western tradition of objective historiography and its assumptions of homogeneity. Rememory, re-imagination becomes a tool in the hands of a minor writer, or a minor community, to revisit and negate received historical narratives that act as exploitative, exclusionary apparatuses of the colonialist attitude. It is exactly this desire for producing an alternative to the past and realizing a future possibility that impels Beloved and Denver to elicit Sethe's stories and encounter the repressed horrors of slavery insofar as the forgetting/ disremembering of the past cannot be fully instigated if one refuses or fails to remember it. The following statement by Shannin Schroeder pulls the threads of this discussion together very neatly:

Since Beloved 'also contains the effects that slavery had, its profound fragmentation of the self and of the connections the self might have with others', she is the alternative to the past. She is also the embodiment of a 'particular historical contradiction' who 'also represents the threat of being engulfed by that past'. If Sethe and the community allow Beloved to engulf their present, they can no longer hope for a future. Thus the 'dangerous power of [the myths of slavery] to rigidify meanings and fix identities' and the linear progression of history must both be explored in order to reorder the community (106 original emphasis). 
It is this experience of slavery that constitutes another point of divergence between Beloved and the mainstream magic realist novels. Following Agnieszka Lobodziec, although Morrison makes use of supernatural elements in her work, she aims to underscore the "uniqueness of AfricanAmerican cultural expressions, including literature, which entail [and originate in] black people's response to [the] oppressive circumstances [of captivity as slaves]" (119). Stressing the importance of this genealogy to her rendition of the African-American experience, Morrison asserts:

"The work that I do frequently falls, in the minds of most people, into that realm of fiction called fantastic, or mythic, or magical, or unbelievable. I'm not comfortable with these labels. I consider that my single gravest responsibility (in spite of that magic) is not to lie" ("Site of Memory" 72).

Whereas magic realism is known for its unidirectional rendering of extraordinary incidents and magical presences as normal, Morrison in Beloved goes even further to rectify the real the ordinary as supernatural and miraculous under the horrific experience of slavery. Once, Amy Denver, a white girl, runs into Sethe while she is escaping from the Sweet Home plantation and notices her swollen feet. "Then she did the magic: lifted Sethe's feet and legs and massaged them until she cried salt tears," saying, "Anything dead coming back to life hurts" (35). Furthermore, Paul D seems to be endowed with an inexplicable natural capability to stir emotions and encourage women to involuntarily open their hearts:

Not even trying, he had become the kind of man who could walk into a house and make the women cry. Because with him, in his presence, they could. There was something blessed in his manner. Women saw him and wanted to weep - to tell him that their chest hurt and their knees did too. Strong women and wise saw him and told him things they only told each other: that way past the Change of Life, desire in them had suddenly become enormous, greedy, more savage than when they were fifteen, and that it embarrassed them and made them sad; that secretly they longed to die - to be quit of it - that sleep was more precious to them than any waking day (17).

Paul D feels a similar sensation beside Sethe in whose presence "[t]he closed portion of his head opened like a greased lock" (41). For another instance, one can point to Denver's interest in the "magic of her birth, its miracle" (29) despite Sethe's helpless condition after escape and her chance encounter with Amy, who helps her to give birth to the baby.

Finally, Morrison's objection to a cursory categorization of Beloved as just another magic realist novel is legitimate to the extent that it might neglect a specifically African-American history, black colonialism and the dehumanizing experience of slavery. This oppressive historical context proves essential to Morrison's portrayal of a reality that is both/ neither empirical and/ nor magical. By navigating the boundary between the magical and the real and by disturbing dichotomous relations established by the major colonialist discourse, Morrison manages effectively to produce a line of escape, a rupture in the system and recover/ invent a new, trans-empirical reality. In this sense, Beloved forms a decolonized and deterritorialized narrative space that subverts and goes beyond the notional centers and assumptions of Western empiricism.

\section{References}

[1] Ahmad, Aijaz. In Theory: Classes, Nations, Literatures. London: Verso, 1992. Print.

[2] Aldea, Eva. "Introduction: Magical Realism." Magical Realism and Deleuze: The Indiscernibility of Difference in Postcolonial Literature. London: Continuum, 2011. 1-18. Print. 
[3] Begoña, Simal González. "Magic Realism in Toni Morrison.” Many Sundry Wits Gathered Together. A Coruña: Servicio De Publicaciones Universidade Da Coruña, 1997. 313-318. Print.

[4] Bensmaia, Réda. "Foreword: The Kafka Effect." Kafka: Towards a Minor Literature. Minneapolis: U Of Minnesota, 1986. IX-XXI. Print.

[5] Brown, William Christopher. "Becoming Origin(al): Deterritorialization and Postcolonial Theory from the Caribbean." FORUM: University of Edinburgh Postgraduate Journal of Culture and the Arts 1 (2005): 110. FORUM. University of Edinburgh. Web. 14 Feb. 2015. http://www.forumjournal.org

[6] Cooper, Brenda. Magical Realism in West African Fiction: Seeing with a Third Eye. London: Routledge, 1998. Print.

[7] Chanady, Amaryll Beatrice. Magical Realism and the Fantastic: Resolved Versus Unresolved Antinomy. New York: Garland, 1985. Print.

[8] Darling, Marsha. "In the Realm of Responsibility: A Conversation with Toni Morrison." Conversations with Toni Morrison. Jackson: U of Mississippi, 1994. 246-254. Print.

[9] Davis, Christina. "An Interview with Toni Morrison." Conversations with Toni Morrison. Jackson: U of Mississippi, 1994. 223-233. Print.

[10] Delaney, Paul. "Decolonization and the Minor Writer." Postcolonial Forum Online (2001): 1-9. Centre for Colonial and Postcolonial Studies. University of Kent. Web. 14 Feb. 2015. http://www.kent.ac.uk/english/postcolonialforum

[11] Deleuze, Gilles, and Felix Guattari. Kafka: Towards a Minor Literature. Minneapolis: U of Minnesota, 1986. Print.

[12] Deleuze, Gilles. Cinema 2: The Time-Image. Minneapolis: U of Minnesota, 1989. Print.

[13] Deleuze, Gilles. Negotiations, 1972-1990. New York: Columbia UP, 1995. Print.

[14] Echevarría, Roberto González. Alejo Carpentier: The Pilgrim At Home. Ithaca, N.Y.: Cornell UP, 1977. Print.

[15] Faris, Wendy B. "Scheherazade's Children: Magical Realism and Postmodern Fiction." Magical Realism: Theory, History, Community. Durham, NC and London: Duke UP, 1995. 163-190. Print.

[16] Hegerfeldt, Anne C. Lies That Tell the Truth: Magic Realism Seen Through Contemporary Fiction from Britain. Amsterdam, New York: Rodopi, 2005. 383. Print.

[17] Hegerfeldt, Anne C. "Magic Realism, Magical Realism." The Literary Encyclopedia. 6 Feb. 2004. Web. 14 Feb. 2015. http://www.litencyc.com

[18] Herman, Luc. Concepts of Realism. Columbia, SC, USA: Camden House, 1996. 246. Print.

[19] Jameson, Fredric. "On Magic Realism in Film.” Critical Inquiry 12.2, Winter (1986): 301-325. Print.

[20] Jameson, Fredric. Postmodernism, Or, The Cultural Logic of Late Capitalism. Durham: Duke UP, 1991. Print.

[21] JanMohamed, Abdul R., and David Lloyd. "Introduction: Toward a Theory of Minority Discourse: What Is To Be Done?" The Nature and Context of Minority Discourse. New York: Oxford UP, 1990. 1-16. Print.

[22] Lister, Rachel. "Toni Morrison and the Novel." Reading Toni Morrison. Santa Barbara, Calif.: Greenwood, 2009. 13-22. Print.

[23] Łobodziec, Agnieszka. "Toni Morrison's Discredited Magic - Magical Realism in Beloved Revisited." Brno Studies in English 38.1 (2012): 103-21. Print.

[24] Morrison, Toni. Beloved: A Novel. New York: Vintage International, 2004. Print.

[25] Morrison, Toni. "The Site of Memory." What Moves at the Margin: Selected Nonfiction. Jackson: U of Mississippi, 2008. 65-82. Print.

[26] O’Sullivan, Simon. "Notes Towards a Minor Art Practice." Drain: Journal of Contemporary Art and Culture, Issue on 'Syncretism', 5, (2005). Drain Magazine. Web. 14 Feb. 2015. www.drainmag.com

[27] Sandín, Lyn Di Iorio, and Richard Perez. Moments of Magical Realism in Us Ethnic Literatures. New York: Palgrave Macmillan, 2013. Print.

[28] Schroeder, Shannin. Rediscovering Magical Realism in the Americas. Westport, Conn.: Praeger, 2004. Print.

[29] Spindler, William. "Magic Realism: A Typology.” Forum for Modern Language Studies 29 (1993): 75-85. Print.

[30] Teraoka, Arlene Akiko. "Gastarbeiterliteratur: The Other Speaks Back." Cultural Critique 7, Fall (1987): 77-101. Print. 